\title{
TRATADOS INTERNACIONAIS E A LEGISLAÇÃO BRASILEIRA SOBRE OS DIREITOS DOS REFUGIADOS
}

INTERNATIONAL TREATIES AND BRAZILIAN LEGISLATION ON REFUGEE RIGHTS

Bruno Carvalho MENEGHETI ${ }^{1}$

ISSUE DOI: 10.21207/2675-0104.2017.657

\begin{abstract}
RESUMO
Nos últimos cinco anos houve um aumento significativo no número de conflitos de longa duração ao redor do mundo, principalmente no norte da África e no Oriente Médio. Tais confrontos têm como características perseguições a civis, seja por diferenças religiosas, étnicas, política e até mesmo nacionalidade. Tantas perseguições culminaram num crescente número de pessoas, e até mesmo famílias inteiras, em situação de refúgio prolongado. O que se tornou um problema para vários países que, tradicionalmente, são procurados por expatriados em busca de ajuda humanitária. Na última década, o Brasil passou por um bom momento, grandes avanços na economia, educação, saúde, distribuição de renda, habitação e empregos. Também houve significativas melhoras legislativas e ainda conta com uma política externa pacífica e com uma diplomacia formidável, mas ainda cheio de desigualdades e problemas estruturais, longe de ser um país ideal. O Brasil tem atraído para dentro de suas fronteiras um montante cada vez maior de refugiados oriundos de diversas partes do globo, a maioria deles chega de países como Síria, Colômbia e Angola. Todos eles acreditando que aqui encontraram ambiente favorável onde poderão se reestabelecer e levar uma vida normal até que possam retornar aos seus lares sem que coloquem em risco as suas vidas e as vidas de seus familiares. $\mathrm{O}$ presente trabalho busca, por meio da pesquisa intensa dos mais relevantes Tratados Internacionais assinados pelo país, formar uma opinião diante da legislação nacional e conferir se a mesma atende aos requisitos e formalidades colocados por tais tratados.
\end{abstract}

PALAVRAS-CHAVE: Tratados Internacioanais; Refugiados; Legislação Brasileira.

\footnotetext{
${ }^{1}$ Discente da Faculdade de Direito de Franca/SP. Bolsista do Programa Interno de Iniciação Cientítica (PIBIC 2016-2017).
} 


\begin{abstract}
In the past five years there has been a significant increase in the number of long-term conflicts around the world, mainly in North Africa and the Middle East. Such clashes are characterized by harassment of civilians, whether due to religious, ethnic, political or even national differences. So many persecutions culminated in an increasing number of people, and even whole families, in a situation of prolonged refuge. This has become a problem for several countries that traditionally are sought after by expatriates in search of humanitarian aid. In the last decade, Brazil has gone through a good moment, great advances in the economy, education, health, income distribution, housing and jobs. There were also significant legislative improvements and it still has a peaceful foreign policy and formidable diplomacy, but still full of inequalities and structural problems, far from being an ideal country. Brazil has attracted an increasing amount of refugees from different parts of the world to its borders, most of them coming from countries like Syria, Colombia and Angola. All of them believing that here they found a favorable environment where they can restore themselves and lead a normal life until they can return to their homes without putting their lives and the lives of their families at risk. The present work seeks, by means of an intense research of the most relevant International Treaties signed by the country, to form an opinion before the national legislation and check if it meets the requirements and formalities set forth by such treaties.
\end{abstract}

Keywords: International Treaties; Refugees; Brazilian legislation.

\title{
INTRODUÇÃO
}

O mundo vive a maior crise humanitária dos últimos 70 anos. Somente a Guerra Civil Síria já causou mais de 5 milhões de refugiados, os diversos conflitos armados espalhados pelo globo infligiram em mais de 60 milhões de pessoas em deslocamento forçado, o Alto Comissariado das Nações Unidas para Refugiados (ACNUR) contabiliza que a cada 113 pessoas, 1 é solicitante de refúgio, deslocada interna ou refugiada. Segundo dados do Comitê Nacional Para os Refugiados (CONARE) são quase 9.000 refugiados vivendo no Brasil e somente em 2015 foram realizadas 28.670 solicitações de refúgio, sendo que apenas 1.231 foram concedidas.

O Brasil um país membro das Nações Unidas, signatário da Convenção de 1951 - Estatuto dos Refugiados, do protocolo de 1967, da Declaração de Cartagena de 1984, e outros dos mais importantes tratados internacionais que dizem respeito aos direitos dos refugiados e direitos humanos. Além do mais, a Constituição da República, em seu artigo $4^{\circ}$, inciso II, a prevalência dos direitos humanos como um princípio das suas relações internacionais. Entretanto, conforme a Convenção de Viena, a assinatura de um tratado, que é de autonomia do poder Executivo, fornece tão somente um aceite precário e provisório, sendo necessário para uma eficácia plena a aprovação pelo poder Legislativo seguida de ratificação pelo Executivo. 
Posto isso, essa pesquisa prisma por buscar no ordenamento jurídico nacional mecanismos que regulamentem os tratados acordados internacionalmente. Além de, incitar o debate de matéria de relevante interesse social.

\section{TRATADOS INTERNACIONAIS SOBRE DIREITOS DOS REFUGIADOS QUE O BRASIL É SIGNATÁRIO}

Diversos são os documentos internacionais que vislumbram assegurar os mais básicos direitos ás pessoas em situação de refúgio, contudo, alguns deles são dotados de maior relevância, sendo eles a Convenção de Genebra de 1951 e o Protocolo Relativo ao Estatuto dos Refugiados de 1967. Ainda que se tratem de documentos distintos e separados, tanto que alguns países ratificaram apenas um deles, ambos são complementares e devem andar atados um ao outro.

\subsection{A CONVENÇÃO DE GENEBRA DE 1951}

A Convenção de Genebra de 1951, também chamada de Convenção das Nações Unidas relativa ao Estatuto dos Refugiados. Tal tratado é de fato o "Estatuto dos Refugiados", sendo o documento internacional mais abrangente e acolhedor sobre o tema, estipulando padrões mínimos de tratamento ao refugiado e servindo de base para todos os posteriores tratados. Neles estão estabelecidos princípios básicos como o de non refoulement, ou não devolução, que impede o repatriamento de refugiados a seus países de origem, enquanto não cessar a perseguição e risco de morte, sendo que José Francisco Sieber Luz Filho2 diz:

Trata-se de princípio inerente à proteção internacional do refugiado, compreendido pela doutrina como o pilar de sua aplicabilidade. Na ausência do princípio a proteção internacional resta vazia e ineficiente (...) A eficácia do princípio do nonRefoulement é conditio sine qua non para a efetiva proteção

\footnotetext{
${ }^{2}$ FILHO, José Francisco Sieber Luz. Non-refoulement: breves considerações sobre o limite jurídico à saída compulsória do refugiado. In:ARAUJO, Nadia de; ALMEIDA, Guilherme Assis de. O direito internacional dos refugiados: uma perspectiva brasileira. Rio de Janeiro: Renovar, p. 179.
} 
internacional, esta última função primordial do direito internacional dos refugiados.

Logo em seu artigo $1^{\circ}$ a Convenção nos dá o conceito formal de refugiado como sendo toda a pessoa que "em consequência dos acontecimentos ocorridos antes de $1^{\circ}$ de janeiro de 1951 e temendo ser perseguida por motivos de raça, religião, nacionalidade, grupo social ou opiniões políticas, se encontra fora do país de sua nacionalidade e que não pode ou, em virtude desse temor, não quer valer-se da proteção desse país, ou que, se não tem nacionalidade e se encontra fora do país no qual tinha sua residência habitual em consequência de tais acontecimentos, não pode ou, devido ao referido temor, não quer voltar a ele.”

Entretanto, tal Convenção objetivava resguardar direitos de europeus que se refugiaram durante a Segunda Grande Guerra, assim sendo, ela coloca um limite geográfico e temporal, limitando-se a proteger europeus que se refugiaram antes de $1^{\circ}$ de janeiro de 1951 , limitações essas que somente foram retiradas posteriormente pelo Protocolo de 1967, relativo ao Estatuto dos Refugiados, que garantiu também outros direitos a classe.

Nos artigos seguintes a Convenção trata de obrigar os refugiados a respeitarem as leis e normas impostas pelo Estado acolhedor que visam a manutenção da ordem pública. Por outro lado, os Estados se comprometem a aplicar tal tratado sem nenhuma discriminação quanto à raça, à religião ou ao país de origem, proporcionar aos refugiados um tratamento ao menos tão favorável quanto o que é proporcionado aos seus nacionais, no que concerne à liberdade religiosa e no que concerne à liberdade de instrução religiosa dos seus filhos.

Como medida de proteção aos refugiados, o Estatuto dos Refugiados, a todo momento, equipara e assegura os mesmos direitos e tratamento recebidos pelos estrangeiros e nacionais dentro dos Estados Nacionais, sempre visando proporcionar direitos básicos e embasado em princípios como o da dignidade da pessoa humana ${ }^{3}$. Como nos casos dos Artigos $7^{\circ}$ e 14 que dizem:

\section{ARTIGO $7^{\circ}$ Dispensa de reciprocidade}

\footnotetext{
${ }^{3}$ Luís Roberto Barroso, A Dignidade da Pessoa Humana no Direito Constitucional Contemporâneo: Natureza Jurídica, Conteúdos Mínimos e Critérios de Aplicação. Versão provisória para debate público. Mimeografado, dezembro de 2010.
} 
1. Ressalvadas as disposições mais favoráveis previstas por esta Convenção, um Estado Parte concederá aos refugiados o regime que concede aos estrangeiros em geral.

2. Após um prazo de residência de três anos, todos os refugiados se beneficiarão, no território dos Estados Partes, da dispensa de reciprocidade legislativa.

3. Cada Estado Parte continuará a conceder aos refugiados os direitos e vantagens de que já gozavam, na ausência de reciprocidade, na data de entrada em vigor desta Convenção para o referido Estado.

Os Estados Partes considerarão com benevolência a possibilidade de conceder aos refugiados, na ausência de reciprocidade, vantagens e direitos além dos que gozam em virtude dos $\S 2^{\circ}$ e $\$ 3^{\circ}$, assim como a possibilidade de conceder o benefício da dispensa de reciprocidade a refugiados que não preencham as condições previstas nos $\S 2^{\circ}$ e $\$ 3^{\circ}$.

As disposições dos $\S 2^{\circ}$ e $\S 3^{\circ}$ acima aplicam-se assim às vantagens mencionadas nos artigos 13, 18, 19, 21 e 22 desta Convenção, como aos direitos e vantagens que não são por ela previstos.

ARTIGO 14 Propriedade intelectual e industrial

Em matéria de proteção da propriedade industrial, especialmente invenções, desenhos, modelos, marcas de fábrica, nome comercial, e em matéria de proteção da propriedade literária, artística e científica, um refugiado se beneficiará, no país em que tem sua residência habitual, da proteção que é conferida aos nacionais do referido país. No território de qualquer um dos outros Estados Partes, ele se beneficiará da proteção dada no referido território aos nacionais do país no qual tem sua residência habitual.

A Convenção se preocupa até mesmo em certificar-se que os refugiados terão acesso ao Judiciário local, e que tal acesso seja amplo e tenham um tratamento tão favorável quanto o fornecido aos nacionais.

O Capítulo III da Convenção é reservado para tratar dos empregos remunerados e não assalariados e, em seu artigo 17 anui que os Estado Nacional criem barreiras para que os refugiados laborem de forma remunerado, contando que tal medida também seja aplicada aos estrangeiros em geral, o texto tenta se justificar alegando que esta providência seria para a "proteção do mercado do trabalho":

Os artigos 18 e 19 protegem aqueles que laboram de forma não assalariada e os profissionais liberais, onde lhes é garantido tratamento tão justo quanto o que é fornecido aos estrangeiros em geral e aos liberais titulares de diplomas válidos e reconhecidos no território em que estão. O artigo 19 deve ser interpretado em conjunto com o artigo 22, que trata da Educação Pública e que pede benevolência aos Estados para o reconhecimento de "diplomas e títulos universitários estrangeiros". O 
artigo 24 diz a respeito da legislação trabalhista e previdenciária, assegurando que aos refugiados tais benefícios devem ser prestados em igualdade aos nacionais, sendo garantidos os mesmos direitos sem distinção.

Enfim, a Convenção de 1951, Relativa ao Estatuto dos Refugiados é um documento muito amplo e abrangente, lidando com diversas matérias pertinentes ao resguardo dos refugiados, tratando de fornecer o conceito de refugiados e suas obrigações com o Estado que lhes acolhe, e garantindo direitos de não discriminação, liberdade religiosa, propriedade privada, propriedade intelectual e industrial, direito de se associar, sustentar ação em juízo, a empregos remunerados, moradia, alimentos, educação e assistência pública, direitos trabalhistas e previdenciários, direito de ir e vir, documentos de viagem e identidade, transferência de bens, não expulsão e não devolução, entre outros.

\subsection{O PROTOCOLO DE 1967, RELATIVO AO ESTATUTO DOS REFUGIADOS}

Conforme disposto no próprio preambulo do Protocolo de 1967, relativo ao Estatuto dos Refugiados, com o passar dos anos e ocorrência de novos acontecimentos, guerras, catástrofes naturais, fome, passaram a existir novas categorias de refugiados que não gozavam da proteção fornecida pelo Estatuto, uma vez que o prazo de $1^{\circ}$ de janeiro de 1951 e o limite geográfico deveriam ser respeitados. Contudo, como já mencionado anteriormente, o Protocolo alargou o conceito de refugiado fornecido pelo art. $1^{\text {o }}$ do Estatuto dos Refugiados ao retirar tais barreiras ${ }^{4}$.

\footnotetext{
${ }^{4}$ Protocolo Relativo ao Estatuto dos Refugiados de 1967 ARTIGO $1^{\circ}$ Disposições Gerais 1. Os Estados Partes no presente Protocolo obrigam-se a aplicar os artigos 2 a 34, inclusive, da Convenção aos refugiados, tal como a seguir definidos. 2. Para os efeitos do presente Protocolo, o termo "refugiado" deverá, exceto em relação à aplicação do $\S 3^{\circ}$ do presente artigo, significar qualquer pessoa que se enquadre na definição dada no artigo primeiro da Convenção, como se as palavras "em decorrência dos acontecimentos ocorridos antes de $1^{\circ}$ de janeiro de 1951 e..." e as palavras "...como consequência de tais acontecimentos" não figurassem do $\$ 2^{\circ}$ da seção A do artigo primeiro. 3. O presente Protocolo será aplicado pelos Estados Partes sem qualquer limitação geográfica; entretanto, serão aplicáveis também, no regime do presente Protocolo, as declarações vigentes feitas por Estados que já sejam Partes da Convenção em conformidade com a alínea "a" do $\S 1^{\circ}$ da seção $B$ do artigo $1^{\circ}$ da Convenção, a menos que as obrigações do Estado declarante tenham sido ampliadas em conformidade com o $\$ 2^{\circ}$ da seção $\mathrm{B}$ do artigo $1^{\circ}$.
} 


\section{O ALTO COMISSARIADO DAS NAÇÕES UNIDAS PARA OS REFUGIADOS - ACNUR}

Trata-se de uma das mais importantes agências humanitárias em atuação, foi criado pela resolução 428 (V) por Assembleia Geral das Nações Unidas em 14 de dezembro de 1950 com o intuito de preservar e resguardar os que sofrem por perseguições, violência e intolerância, fornecendo proteção internacional aos refugiados que se enquadrem nos requisitos estabelecidos pelo Estatuto dos Refugiados. Tem o status de órgão subsidiário, contudo, atua de maneira independente seguindo as diretivas traçadas pela Assembleia Geral e pelo Conselho Econômico e Social.

Conforme estabelecido no próprio estatuto do ACNUR, os trabalhos realizados pelo Alto-comissariado são totalmente apolíticos, humanitários e sociais ${ }^{5}$. É subordinada a Assembleia Geral e ao Conselho Econômico e Social da ONU ${ }^{6}$.

O ACNUR é diretamente subordinado ao Secretário Geral das Nações Unidas e que trabalha assistido pelo Comitê Executivo que, segundo dados do próprio ACNUR ${ }^{7}$, possui um orçamento anual de US\$ 3 bilhões por ano, valor este proveniente de doações e contribuições de diversos países uma vez que, diferentemente de outras agencias geridas também pelas Nações Unidas, toda a verba da Agencia é arrecadada pelas enormes campanhas de captação de recursos desenvolvidas ao redor do globo.

Tem como sede seu escritório central na cidade suíça de Genebra, lá trabalham 705 funcionários dos mais de 7200 empregados pelo ACNUR. Os remanescentes são empregados no campo e auxiliam diretamente os refugiados. É chefiado pelo Alto Comissário, eleito em Assembleia Geral e nomeado segundo o Secretário-Geral ${ }^{8}$, cabe ao

\footnotetext{
${ }^{5}$ Estatuto da ACNUR, ANEXO, CAPÍTULO I - Disposições Gerais, Item 2. O trabalho do Alto Comissariado terá um caráter totalmente apolítico; será humanitário e social e, como regra geral, estará relacionado com grupos e categorias de refugiados.

${ }^{6}$ Estatuto da ACNUR, ANEXO, CAPÍTULO I - Disposições Gerais, Item 3. O Alto Comissariado seguirá as diretrizes fornecidas pela Assembléia Geral ou pelo Conselho Econômico e Social.

7 BREVE HISTÓRICO DO ACNUR, DISPONÍVEL EM: HTTP://WWW.ACNUR.ORG/PORTUGUES/INFORMACAO-GERAL/BREVE-HISTORICO-DO-ACNUR/, ACESSADO EM 28 DE JULHO DE 2017.

${ }^{8}$ Estatuto da ACNUR, ANEXO, CAPÍTULO III - Organização e Financiamento, Item 13. O Alto Comissário será eleito pela Assembléia Geral sob nomeação do Secretário-Geral. O mandato será
} 
Alto Comissário designar um Adjunto a sua função de nacionalidade diversa da sua própria ${ }^{9}$. Cabe ao Alto Comissário, dentro dos limites orçamentários, nomear os funcionários do Alto Comissariado, sendo que deverão ser designadas pessoas devotas à causa do Comissariado $^{10}$.

A atuação do Alto Comissariado se estende por 126 países, principalmente nas zonas de conflito, áreas arrasadas por catástrofes naturais e nas operações de repatriação de refugiados.

É estimado que mais de 43 milhões de pessoas, espalhadas por todos os continentes, estão incorporadas no interesse do ACNUR como solicitantes de refúgio, refugiados de fato, apátridas, deslocados internos e repatriados.

O trabalho do ACNUR tem foco nas questões legais e diplomáticas e sua principal função é prover proteção internacional aos refugiados e buscar soluções duradouras a tamanho revés. Missão consoante com os princípios expostos pela Carta das Nações Unidas ${ }^{11}$ quando elege a manutenção da paz e segurança internacionais; desenvolvimento de relações amistosas entre as nações; e encorajamento do respeito pelos direitos humanos e pelas liberdades fundamentais como alguns de seus baluartes.

proposto pelo Secretário-Geral e aprovado pela Assembléia Geral. O Alto Comissário será eleito por um período de três anos, com início em $1^{\circ}$ de Janeiro de 1951.

${ }^{9}$ Estatuto da ACNUR, ANEXO, CAPÍTULO III - Organização e Financiamento, Item 14. O Alto Comissário designará, pelo mesmo período, um Alto Comissário Adjunto, de nacionalidade diferente da sua.

${ }^{10}$ Estatuto da ACNUR, ANEXO, CAPÍTULO III - Organização e Financiamento, Item 15. (a) Dentro dos limites orçamentários, o Alto Comissário nomeará os funcionários do Alto Comissariado, os quais serão, no exercício das suas funções, perante ele responsáveis. (b) Tais funcionários deverão ser escolhidos entre pessoas devotadas à causa do Alto Comissariado. (c) As suas condições de emprego serão previstas no regulamento de funcionários aprovado pela Assembléia Geral e nas disposições estabelecidas pelo Secretário-Geral, em aplicação desse regulamento. (d) Tais condições podem também permitir o emprego de pessoal não-remunerado.

${ }^{11}$ Carta das Nações Unidas, Capítulo I, Propósito e Princípios - Artigo 1. Os propósitos das Nações unidas são: 1. Manter a paz e a segurança internacionais e, para esse fim: tomar, coletivamente, medidas efetivas para evitar ameaças à paz e reprimir os atos de agressão ou outra qualquer ruptura da paz e chegar, por meios pacíficos e de conformidade com os princípios da justiça e do direito internacional, a um ajuste ou solução das controvérsias ou situações que possam levar a uma perturbação da paz; 2 . Desenvolver relações amistosas entre as nações, baseadas no respeito ao princípio de igualdade de direitos e de autodeterminação dos povos, e tomar outras medidas apropriadas ao fortalecimento da paz universal; 3. Conseguir uma cooperação internacional para resolver os problemas internacionais de caráter econômico, social, cultural ou humanitário, e para promover e estimular o respeito aos direitos humanos e às liberdades fundamentais para todos, sem distinção de raça, sexo, língua ou religião; e 4. Ser um centro destinado a harmonizar a ação das nações para a consecução desses objetivos comuns. 
Um dos grandes objetivos do Alto Comissariado é a busca por soluções permanentes para a questão dos refugiados, e são lançadas três táticas para se alcançar tal pretensão, sendo a primeira e mais efetiva a repatriação voluntária, ou seja, o regresso dos refugiados para os seus países de origem findados os motivos que ocasionaram a sua fuga - é tida por muitos como a melhor solução, sendo a única que não priva o ente de sua origem; quando não se é possível a repatriação o ACNUR tenta, principalmente por meio do trabalho e educação, inserir os refugiados na nova sociedade em que foram acolhidos; por último e sendo a mais incomoda das alternativas mas muitas vezes a necessária, se tem o reassentamento quando o refugiado se encontra em um país diferente do seu mas ali ainda persistem os riscos a sua segurança e se faz mister movelo para um terceiro Estado.

Trabalha também o Alto Comissariado estimulando medidas dos Estados que prezam pela estabilidade local, assim evitando a criação ou o aumento dos fluxos de refugiados. Tais medidas são fomentadas pois o ACNUR se preocupa em resolver de forma permanente a questão dos refugiados.

\section{LEGISLAÇÃO BRASILEIRA SOBRE REFUGIADOS}

Desde 1960 o Brasil é signatário da Convenção de Genebra de 1951 contudo, logo após sua assinatura o país viveu um longo período ditatorial, sendo que o regime militar forçava a saída de muitos brasileiros para o exterior em busca de refúgio. Assim sendo, durante os anos que vigoraram o regime de exceção não houve movimentação governamental no sentido de bem abrigar refugiados no país, nem projetos do ACNUR, uma vez que o Comissariado se preocupava com o movimento inverso, a fuga de brasileiros para o exterior. Posto isso, durantes tais anos quem se ocupou intensamente com a questão dos refugiados em terras brasileiras foi a Igreja Católica, representada pelas Cáritas Arquidiocesanas do Rio de Janeiro e a de São Paulo.

Apenas no ano de 1970 que pode o ACNUR, em acordo com o governo brasileiro, abrir um escritório no país. Foi montado na capital carioca, entretanto, as autoridades brasileiras não reconheciam o Alto Comissariado como um órgão subsidiário e mandatário das Nações Unidas. Durante toda a ditadura quem liderava as ações em favor dos refugiados 
eram os cardeais, uma vez que a Igreja Católica gozava de grande prestigio por partes dos líderes das Forças Armadas.

Com o fim do regime, a redemocratização e a Constituição da República de 1988 consagrando a dignidade humana logo em seu artigo primeiro como um de seus princípios básicos ${ }^{12}$, pode o ACNUR finalmente se fazer presente de forma oficial no Brasil e seu primeiro compromisso foi pressionar para que o Brasil tirasse a reserva geográfica feita ao assinar a Convenção de Genebra de 1951, que tomava por refugiados somente aqueles que fugiram da Europa ${ }^{13}$. O que foi feito definitivamente somente em 1989 por meio do decreto presidencial de número 98.602, do então Presidente da República José Sarney.

Até o final de 1992 o governo brasileiro agia minimamente frente a tão grave assunto, tomando apenas pequenas ações, uma vez que se limitava tão somente a liberação de documentos para os refugiados selecionados e que tinham o pedido de reconhecimento formal feito pelo ACNUR. Logo após a emissão de seus documentos os refugiados deveriam seguir seus próprios rumos para se reestabelecerem, o que definitivamente era insuficiente, certo de que muitos não conheciam a língua portuguesa, os costumes brasileiros e eram provenientes de zonas de conflito e perseguição, muitos necessitando deles de tratamento psicológico e ou médico, além de suporte financeiro.

Foi percebido que era preciso um mecanismo mais eficiente para reger e regulamentar o Estatuto dos Refugiados no Brasil, era necessário também a criação de um ente estatal que se incumbisse em receber os pedidos de refúgio e organizasse os processos de aceitação e reconhecimento. Assim surgiu a Lei 9.474 de 22 de julho de 1997.

\footnotetext{
${ }^{12}$ Constituição da República Federativa do Brasil de 1988 Art. $1^{\circ}$ A República Federativa do Brasil, formada pela união indissolúvel dos Estados e Municípios e do Distrito Federal, constitui-se em Estado Democrático de Direito e tem como fundamentos: I - a soberania; II - a cidadania III - a dignidade da pessoa humana; IV - os valores sociais do trabalho e da livre iniciativa; V - o pluralismo político. Parágrafo único. Todo o poder emana do povo, que o exerce por meio de representantes eleitos ou diretamente, nos termos desta Constituição.

13 Convenção de 1951, Relativa ao Estatuto dos Refugiados, CAPÍTULO I Disposições Gerais ARTIGO $1^{\circ}$ Definição do termo "refugiado": B.(1). Para os fins da presente Convenção, as palavras

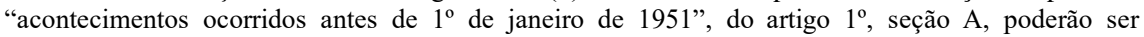
compreendidas no sentido de: a) "acontecimentos ocorridos antes de $1^{\circ}$ de janeiro de 1951 na Europa"; b) "acontecimentos ocorridos antes de $1^{\circ}$ de janeiro de 1951 na Europa ou alhures". e cada Estado Parte fará, no momento da assinatura, da ratificação ou da adesão, uma declaração precisando o alcance que pretende dar a essa expressão, do ponto de vista das obrigações assumidas por ele em virtude da presente Convenção.
} 
Dentro do arcabouço nacional diversas são as resoluções normativas de órgãos governamentais, decretos presidenciais e legislativos tratando de ratificar múltiplos tratados internacionais e até mesmo leis federais e ordinárias para regulamentar internamente tais tratados.

\subsection{LEI № 9.474 DE 22 DE JULHO DE 1997}

Sem sombra de dúvidas a mais importante lei nacional sobre o tema é a Lei $\mathrm{N}^{\circ} 9.474$ de 22 de Julho de $1997^{14}$, sua relevância é enorme uma vez que regulamenta o Estatuto dos Refugiados juntamente com o Protocolo Relativo ao Estatuto dos Refugiados de 1967 e cria o CONARE - Comitê Nacional para os Refugiados, órgão interministerial que tem como principal função zelar pelos refugiados que se encontram em terras brasileiras.

Segundo o próprio CONARE a Lei 9.474 "transmite regras mais claras e mais diretas aos órgãos da administração pública. Mostrou-se eficaz para maior envolvimento do Brasil com o tema do refúgio. ", além de ser "considerada hoje pela própria ONU como uma das leis mais modernas, mais abrangentes e mais generosas do mundo. Contempla todos os dispositivos de proteção internacional de refugiados e cria um órgão nacional - o Comitê Nacional para os Refugiados (Conare) - para ditar a política pública do refúgio e decidir quanto às solicitações de refúgio apresentadas no Brasil.". ${ }^{15}$

Em seu artigo primeiro a Lei 9.474 trata de passar quem poderá ser considerado refugiado perante o direito brasileiro. Assim sendo diz que:

\footnotetext{
Será reconhecido como refugiados todo indivíduo que:

I - devido a fundados temores de perseguição por motivos de raça, religião, nacionalidade, grupo social ou opiniões políticas encontrese fora de seu país de nacionalidade e não possa ou não queira acolher-se à proteção de tal país;

II - não tendo nacionalidade e estando fora do país onde antes teve sua residência habitual, não possa ou não queira regressar a ele, em função das circunstâncias descritas no inciso anterior;
}

\footnotetext{
${ }^{14}$ LEI No 9.474, DE 22 DE JULHO DE 1997 Diário Oficial da União no 139 - Seção I - Páginas 15822 15824 -23 de julho de 1997

${ }^{15}$ Refúgio no Brasil: a proteção brasileira aos refugiados e seu impacto nas Américas / Luiz Paulo Teles Ferreira Barreto, organizador. - 1. ed. -Brasília: ACNUR, Ministério da Justiça, 2010
} 
III - devido a grave e generalizada violação de direitos humanos, é obrigado a deixar seu país de nacionalidade para buscar refúgio em outro país.

Já no artigo segundo o legislador se preocupou em expandir a aplicação do conceito fornecido pelo artigo primeiro, considerando também como refugiado todo o grupo familiar a qual pertença um membro oriundo de migração forçada que se encontra em território nacional, não importando seu sexo, idade, seja ele ascendente, descendente ou qualquer outro integrante do grupo familiar e economicamente dependente da pessoa refugiada.

Artigo $2^{\circ}$ - Os efeitos da condição dos refugiados serão extensivos ao cônjuge, aos ascendentes e descendentes, assim como aos demais membros do grupo familiar que do refugiado dependerem economicamente, desde que se encontrem em território nacional.

Em seu artigo quinto, localizado no capítulo referente a condição jurídica dos refugiados, a lei concede aos refugiados os direitos dos estrangeiros residentes no Brasil, contudo, os imputa com os mesmos deveres e também com a obrigação de respeitar as leis, regulamentos e providências necessárias à ordem pública.

\footnotetext{
Artigo $5^{\circ}$ - O refugiado gozará de direitos e estará sujeito aos deveres dos estrangeiros no Brasil, ao disposto nesta Lei, na Convenção sobre o Estatuto dos Refugiados de 1951e no Protocolo sobre o Estatuto dos Refugiados de 1967, cabendo-lhe a obrigação de acatar as leis, regulamentos e providências destinados à manutenção da ordem pública.
}

Muito importante se faz o artigo sexto, localizado no mesmo capítulo que o artigo quinto, quando concede ao refugiado cédula de identidade que comprove sua condição jurídica, carteira de trabalho e documento de viagem.

O Título II da Lei 9.474 diz respeito ao "Ingresso no Território Nacional e do Pedido de Refúgio", e é destaque sua posição de permitir que o pedido de refúgio seja solicitado a qualquer autoridade migratória que for encontrada em faixa de fronteira, sendo de obrigação do solicitado de informar o procedimento que deverá ser tomado e todas as informações necessárias. Também garante ao refugiado que em hipótese alguma será deportado para fora do território nacional, expondo sua vida e liberdade, salvo se o refugiado for tido como perigoso para a segurança brasileira, importante frisar que, diferentemente de algumas outras legislações latino- 
americanas, a Lei 9.474/97 não estipula um tempo máximo que o pedido possa ser solicitado.

Artigo $7^{\circ}$ - O estrangeiro que chegar ao território nacional poderá expressar sua vontade de solicitar reconhecimento como refugiado a qualquer autoridade migratória que se encontre na fronteira, a qual lhe proporcionará as informações necessárias quanto ao procedimento cabível.

$\S 1^{\circ}$ Em hipótese alguma será efetuada sua deportação para fronteira de território em que sua vida ou liberdade esteja ameaçada, em virtude de raça, religião, nacionalidade, grupo social ou opinião política.

$\S 2^{\circ} \mathrm{O}$ benefício previsto neste artigo não poderá ser invocado por refugiado considerado perigoso para a segurança do Brasil.

Tão importante quanto é o artigo oitavo que não impede aqueles que adentraram o território brasileiro de forma irregular de solicitar o status de refugiado:

Artigo $8^{\circ}$ - O ingresso irregular no território nacional não constitui impedimento para o estrangeiro solicitar refúgio às autoridades competentes.

No artigo 10 resta esclarecido que se já existente algum processo administrativo ou até mesmo criminal dado ao ingresso irregular no território nacional, a solicitação de refúgio paralisará tais atos até que se encerre os tramites do procedimento de refúgio. Sendo concedido o refúgio ao final, todos os processos serão arquivados.

Artigo 10 - A solicitação, apresentada nas condições previstas nos artigos anteriores, suspenderá qualquer procedimento administrativo ou criminal pela entrada irregular, instaurado contra o peticionário e pessoas de seu grupo familiar que o acompanhem.

$\S 1^{\circ}$ Se a condição de refugiado for reconhecida, o procedimento será arquivado, desde que demonstrado que a infração correspondente foi determinada pelos mesmos fatos que justificaram o dito reconhecimento.

O Título III da Lei 9747/97 trata da criação e organização do CONARE e será tratado em item próprio

Em seu quarto Título a Lei 9474/97 descreve como deverá acontecer o processo de refúgio, sendo o Capítulo I destinado a narrar o procedimento. Em conformidade com o artigo $7^{\circ}$, outrora mencionado, o 
artigo 17 coloca que o estrangeiro deverá se apresentar à autoridade competente e expressar seu interesse em obter o reconhecimento como refugiado. Por sua vez, o artigo 18 elege que o procedimento terá início quando o solicitante for notificado pela autoridade para que preste as devidas declarações, sendo que o ACNUR deverá ser informado da existência de novo processo solicitado e poderá fazer sugestões que agilizem seu andamento. As declarações exigidas pelo caput do artigo 18 são detalhadas no artigo seguinte que também rege a forma como deverão ser colhidas.

Após solicitado o refúgio, será emitido pelo Departamento de Polícia Federal protocolo de autorização de residência provisória em favor do solicitante e de todos os demais membros de seu grupo familiar que se encontrem no Brasil. Com a Autorização de Residência Provisória, será possível a emissão por parte do Ministério do Trabalho da Carteira de Trabalho Provisória, importantíssimo documento resguardado pela presente lei, uma vez que permite ao refugiado laborar de formar regular ou mesmo buscar emprego formal, trazendo maior segurança ao empregador e, principalmente, ao próprio refugiado que contará com seus direitos trabalhistas ainda mais bem protegidos ${ }^{16}$. Durante a vigência da autorização provisória, ou seja, no intervalo de tempo entre a solicitação até o final do processo, será aplicada a legislação referente aos estrangeiros.

Serão realizadas pela Polícia federal as diligências requeridas pelo Comitê e necessárias para se averiguar os fatos levados a conhecimento pelo solicitante de refúgio, sempre respeitando o princípio da confidencialidade, sendo que todos que tiveram contato com o as informações constantes no processo deverão guardar sigilo, objetivando uma rápida e célere decisão e que não exponha os solicitantes.

Fundamentada deve ser a decisão que reconhece ou nega a condição de refugiado, sendo que possui caráter de ato declaratório. Uma vez proferida a sentença deverá o CONARE notificar o solicitante além do Departamento de Polícia Federal para que tome as medidas cabíveis, seja o seu registro junto ao próprio Departamento, contendo assinatura no termo de responsabilidade e a solicitação de carteira de identidade permanente.

\footnotetext{
${ }^{16}$ Lei 9474/97 Artigo 21 - Recebida a solicitação de refúgio, o Departamento de Polícia Federal emitirá protocolo em favor do solicitante e de seu grupo familiar que se encontre no território nacional, o qual autorizará a estada até a decisão final do processo. (ver resolução normativa 006) $\S 1^{\circ} \mathrm{O}$ protocolo permitirá ao Ministério do Trabalho expedir a carteira de trabalho provisória, para o exercício de atividades remuneradas no País.
} 
Se negado o pedido, caberá recurso ao próprio Ministro da Justiça, aquele quem indica o presidente do Comitê. Enquanto processado o recurso poderá o solicitante e sua família permanecerem em território brasileiro. Contudo, caso seja desfavorável ao solicitante a decisão do Ministro de Estado da Justiça, não caberá mais recurso, contudo, o solicitante não será enviado ao seu país de origem, podendo permanecer no Brasil sobe o resguardo da legislação cabível aos estrangeiros em geral.

Sendo que, não poderão ser extraditados aqueles que obtiveram a concessão do status de refugiado e até mesmo a simples solicitação de refúgio é o bastante para suspender qualquer processo de extradição existente, seja ele administrativo ou judicial.

Quando expulso um refugiado do Brasil deverá ser por comprovado motivo de segurança nacional ou de ordem pública e mesmo assim, jamais será deportado a um país que coloque em insegurança seus direitos a vida, liberdade ou integridade física. Deverá ser certo que a sua admissão em país estrangeiro não resulte em perseguição.

\subsection{O COMITÊ NACIONAL PARA OS REFUGIADOS - CONARE}

É clara a importância do CONARE no âmbito nacional, é por ele que o Poder Executivo se encarrega por controlar a entrada e saída de refugiados por todo o território nacional, sendo o responsável no país por ditar a política pública sobre tais direitos.

O Título III criou e deu forma ao já mencionado CONARE, que conforme a própria lei é um "órgão de deliberação coletiva, no âmbito do Ministério da Justiça", ou seja, um órgão colegiado com a função de determinar a condição de refugiado no Brasil. Conta não somente com participação exclusiva do governo, tendo também participação de representantes da sociedade civil, das Nações Unidas - por meio do ACNUR e também por membros das Cáritas Arquidiocesanas do Rio de Janeiro e de São Paulo. Sendo sua formação expressa no artigo 14 da lei 9.474: 
IV - um representante do Ministério da Saúde;

V - um representante do Ministério da Educação e do Desporto;

VI - um representante Departamento de Polícia Federal;

VII - um representante de organização não governamental, que se dedique a atividades de assistência e proteção de refugiados no País.

Sendo que, conforme os parágrafos do próprio artigo 14, o ACNUR é apenas membro convidado, sem direito a voto, somente com direito a palavra. Tendo seus membros designados pelo próprio Presidente da República, mediante as indicações ofertados pelos órgãos e entidades que compõem o comitê.

Interessante o posicionamento brasileiro de colocar um representante da sociedade civil com direito a voto, uma vez que adere maior confiabilidade e lisura a todo o processo, além de permitir que as partes da sociedade que estão ligadas ao auxílio dos refugiados tomem parte de políticas públicas ${ }^{17}$.

Também se encontra regulamentada na mesma lei a competência do CONARE:

Artigo 12 - Compete ao CONARE, em consonância com a Convenção sobre o Estatuto dos Refugiados de 1951, com o Protocolo sobre o Estatuto dos Refugiados de 1967 e com as demais fontes de direito internacional dos refugiados: I - analisar o pedido e declarar o reconhecimento, em primeira instância, da condição de refugiado; II - decidir a cessação, em primeira instância, ex officio ou mediante requerimento das autoridades competentes, da condição de refugiado; III - determinar a perda, em primeira instância, da condição de refugiado; IV - orientar e coordenar as ações necessárias à eficácia da proteção, assistência e apoio jurídico aos refugiados; V - aprovar instruções normativas esclarecedoras à execução desta Lei.

Assim, fica evidente que não somente o CONARE deve decidir quem se enquadra na norma do artigo $1^{\circ}$ e faz jus ao status de refugiado, a ele compete também assegurar todas as atitudes que competem para uma eficiente proteção ao refugiado.

\footnotetext{
${ }^{17}$ Alguns autores colocam que foi dado poder do voto a membros da sociedade civil e direito a fala do ACNUR para que fosse dissipado entre o Estado, a sociedade e o representante da ONU as responsabilidades em relação aos refugiados. JUBILUT, Liliana Lyra; APOLINÁRIO, Silvia Menicucci de Oliveira Selmi. Refugee Status Determination in Brazil: A Tripartite Enterprise. Refuge -Canada's Periodical on Refugees, v.25, n. 2, p. 29-38, 2009, p. 34.
} 
Evidente se mostra que o Brasil conta com uma avançada, bem organizada e vasta legislação a respeito dos direitos dos refugiados. Os mais importantes tratados internacionais assinados pelo país e de maior relevância internacional passaram pelo crivo do legislativo e se encontram espalhados por nossa legislação, mais precisamente na Lei 9474/97. Sendo essa uma lei de vanguarda, considerada até pela própria ONU

Contamos com um bom e bem estabelecido órgão estatal com a missão de aferir quais os estrangeiros realmente se enquadram nos requisitos internacionalmente estabelecidos para se adquirir o status de refugiado, entretanto, por se tratar de uma instituição muito recente, falta ainda aperfeiçoamento no quesito publicidade, transparência e segurança jurídica em suas decisões.

Com esses sinais é possível afirmar que o Brasil possui políticas públicas e se preocupa em bem receber refugiados, todavia, poderiam existir maiores esforços governamentais no que tange a inclusão dos refugiados na sociedade e trabalhar para existir uma maior celeridade do trâmite dos pedidos e recursos que objetivam a concessão do refúgio.

\section{REFERÊNCIAS BIBLIOGRÁFICAS}

REZEK, José Francisco. Direito internacional público: curso elementar / Francisco Rezek. 13 ed. Ver., aumen. e atual. São Paulo: Saraiva, 2011.

GOYOS JUNIOR, Durval de Noronha. O Novo Direito Internacional Público: (e o embate contra a tirania) / Durval de Noronha Goyos Junior. - São Paulo: Observador Legal, 2005.

Piovesan, Flávia. Direitos humanos e o direito constitucional internacional / Flávia Piovesan. - 10 ed. Ver. E atual. - São Paulo : Saraiva, 2009.

<https://jus.com.br/artigos/51131/o-principio-de-non-refoulement-nao-devolucao-X-refugiadoshumanitarios> Acesso em: 20 de março de 2017

$<$ https://blog.ebeji.com.br/principio-do-non-refoulement-em-sede-de-refugio/> Acesso em: 15 de abril de 2017

<http://www2.camara.leg.br/legin/fed/decret/1960-1969/decreto-50215-28-janeiro-1961-389887publicacaooriginal-1-pe.html> Acesso em: 06 de maio de 2017

<http://www.acnur.org/portugues/informacao-geral/o-que-e-a-convencao-de-1951/> Acesso em: 12 maio de 2017

<http://www.luisrobertobarroso.com.br/wp-

content/themes/LRB/pdf/a_dignidade_da_pessoa_humana_no_direito_constitucional.pdf>

Acesso em: 12 maio de 2017

$<$ http://www.acnur.org/portugues/informacao-geral/o-alto-comissario/> Acesso em: 12 maio de 2017

$<$ http://www.acnur.org/portugues/informacao-geral/breve-historico-do-acnur/> Acesso em: 04 junho de 2017 
<http://www.acnur.org/portugues/informacao-geral/o-comite-executivo-excom/> Acesso em: $31 \mathrm{de}$ julho de 2017

<http://www.planalto.gov.br/ccivil_03/decreto/1930-1949/d19841.htm> Acesso em: 28 de setembro de 2017

<http://www.acnur.org/t3/fileadmin/Documentos/portugues/Publicacoes/2010/Refugio_no_Brasil.pdf $>$ Acesso em: 01 maio de 2017

<http://www.planalto.gov.br/ccivil_03/decreto/1930-1949/d19841.htm> Acesso em: 18 de maio de 2017

<http://www2.camara.leg.br/legin/fed/decret/1989/decreto-98602-19-dezembro-1989-325506-

publicacaooriginal-1-pe.html> Acesso em: 29 agosto de 2017

<http://www.acnur.org/portugues/noticias/noticia/brasil-tem-quase-9-mil-refugiados-de-79nacionalidades/> Acesso em: 05 de julho de 2017

$<$ http://g1.globo.com/distrito-federal/noticia/2016/05/pedidos-de-refugio-no-brasil-crescem-2868em-cinco-anos-diz-justica.html> Acesso em: 05 de julho de 2017

$<$ http://www.justica.gov.br/central-de-atendimento/estrangeiros/refugio> Acesso em: 06 de julho de 2017

<http://caminhosdorefugio.com.br/tag/conare/> Acesso em: 07 de julho de 2017

$\langle$ http://pesquisa.in.gov.br/imprensa/jsp/visualiza/index.jsp?jornal=1\&pagina $=56 \&$ data $=11 / 11 / 2016>$

Acesso em: 07 de julho de 2017 